\title{
Effects of Cigarette Smoke Exposure on Placental Global DNA Methylation and 8-hydroxy-2'- deoxyguanosine Levels in Mother-new-born Binomials
}

Hector Diaz-Garcia

Instituto Politécnico Nacional

Jenny Vilchis-Gil

Hospital Infantil de México Federico Gómez

\section{Karla Viridiana Castro-Cerritos}

Instituto de Química Aplicada, Universidad del Papaloapan, Tuxtepec, Oaxaca, Mexico

Pilar García-Roca

Hospital Infantil de México Federico Gómez

Miguel Klünder-Klünder

Hospital Infantil de México Federico Gómez

Jaqueline Gómez-López

Hospital Militar de Especialidades de la Mujer y Neonatología, Secretaria de la Defensa Nacional, Mexico

City, Mexico

Javier Tadeo Granados-Riveron

Hospital Infantil de México Federico Gómez

\section{Adolfo López-Torres}

Instituto de Química Aplicada, Universidad del Papaloapan, Tuxtepec, Oaxaca, Mexico

Rocio Sánchez-Urbina ( $\square$ roci0404@gmail.com )

Hospital Infantil de México Federico Gómez

\section{Research Article}

Keywords: Cigarette smoking, pregnancy, dietary intake, 8-hydroxy-2'-deoxyguanosine, methylated DNA

Posted Date: December 17th, 2021

DOI: https://doi.org/10.21203/rs.3.rs-1125181/v1

License: (9) (1) This work is licensed under a Creative Commons Attribution 4.0 International License. Read Full License 


\section{Abstract}

Background: Smoking is practiced worldwide for both men and women, and it is associated with different diseases and deleterious effects on gestational products, chiefly during pregnancy. Epigenetic alterations induced by cigarette smoke must be related to perinatal abnormalities.

Methods: 219 pregnant women, aged 16 to 34 years, with or without a history of cigarette consumption (1$5 /$ day) during the first trimester of pregnancy and their offspring were studied in this work. A validated dietary questionnaire was used to estimate daily consumptions of macronutrients and micronutrients, including total energy, during pregnancy. As a marker of DNA damage, 8-hydroxy-2'-deoxyguanosine (8-OHdG) levels were determined in plasma of women, before delivery, in umbilical cord blood after delivery, in the new-borns. The proportion of methylated DNA in the placentas (metDNA) was determined by ultra-high-performance liquid chromatography coupled with high-resolution mass spectrometry (UPLC-HRMS).

Results: Non-significant differences were observed between smoking and non-smoking women groups, or between the new-borns groups ( $p>0.05)$. Smoking women showed up higher intakes of vitamins, lipids, proteins, and carbohydrates in comparison with non-smoking women $(p<0.01)$. 8-OHdG levels correlated among the mothers and new-borns $(p=5.386 \mathrm{e}-15)$ and were lower in the smoking binomials in comparison with non-smoking binomials $(\beta=-1.20$ to -64$)$. Negative correlations were found between micronutrients and macronutrients but Vitamin $C$, and 8-OHdG levels of the women $(p<0.01)$. However, the new-borns 8-OHdG correlated with proteins, vitamin A, and vitamin B12 $(p<0.05)$. Cigarettes consumed per day correlated to the 8-8HdG levels (Rho $=-0.247, p=0.012$ ), alcohol consumption ( $R h o=0.219, p=0.001$ ), to macronutrients $(\mathrm{Rho}=212$ to $332, p<0.01)$, micronutrients (Rho $=186$ to $289, p<0.01)$, and to energy (Rho $=0.286, p=$ $0.001)$. Finally, metDNA deceased in the smoking women than in the non-smoking women $(\beta=-0.12, p<$ $0.05)$, and correlated with the number of cigarettes consumed per day (Rho $=-0.229, p=0.009)$.

Conclusion: Cigarette smoking alters metDNA levels of the placenta, however, their clinical effects come out over years or transgenerationally.

\section{Introduction}

Tobacco smoking is a public health problem [1], and it is related to mortality owing to its association with cardiovascular diseases or cancer [2], amongst other pathologies. Only in Mexico, there were more than 14 million adult smokers in 2016, of whom $25.3 \%$ were women with an average age at onset of a smoking habit of 21-year-old [3]. In some countries, smoking is frequent amongst pregnant women, with a prevalence of up to $25 \%$ [4].

Children are susceptible to environmental factors during pregnancy, mainly maternal conditions such as nutrition [5, 6], type 2 diabetes (T2D) or obesity [6-8], cigarette smoke [9, 10], or alcohol [11, 12]. Maternal smoking has immediate or midterm deleterious effects such as preterm pregnancy [13-15], low birth weight [15], congenital anomalies [16, 17], chronic asthma [4, 18-20], bronchiolitis [4, 21], or psychiatric abnormalities [22-25]. The aetiology of those conditions might be the result of epigenetic modifications during embryonic or foetal development. 
Studies on the placenta and umbilical cord blood DNA methylation have found significant differences between smoking women and non-smoking women [26-29] associated with abnormalities in their offspring [9]. On the other hand, pregestational maternal nutrition status can alter the placenta methylation [30, 31], e.g., high or low DNA methylation level is associated with mothers' glucose levels [32, 33].

The smoke cigarette is characterized by an enormous production of free radicals that can oxide the DNA via hydroxyl radical formation through Fenton reactions $[34,35]$. From the four nucleotides of DNA, guanine is the most susceptible to oxidation [36]. Guanine oxidation gives rise to 8-hydroxy-2'-deoxyguanosine (8-OHdG), 8OHdG pairs easily with thymine instead of cytosine, causing $G \rightarrow T$ transversions. That can alter the DNA methylation pattern whether $\mathrm{G}$ in $\mathrm{CpG}$ 's islands are modified but non-reverted [37]. Concerning the prior, 8OHdG has been associated with DNA damage [38] and changes in the DNA pattern methylation [39]. On the other hand, an everyday fruit intake decreases the urinary 8-OHdG secretion [40].

Based on previously described, in this work we studied the association between maternal smoking and diet with DNA damage (8-OHdG) in mother-child pairs and the overall methylation percentage in placental tissue change in smoking women as compared with non-smoking women.

\section{Methods}

\section{Participants}

From January 2015 to July 2016, 219 healthy pregnant women were recruited during their third trimester of pregnancy for this cross-sectional study. All women signed an informed consent form. The study was conducted in accordance with the latest version of the Declaration of Helsinki, and the study protocol was approved by the committees for the investigation, Ethics and Biosecurity of the Hospital Infantil de Mexico Federico Gómez. The inclusion criteria were women who delivered at gestational ages of 38 to 40 weeks from the last menstruation and had adequate prenatal control, including monthly medical consultations from the first trimester of pregnancy and a minimum of two normal prenatal ultrasonography results. Women who had pre-eclampsia, T1D or T2D, obesity, or gestational diabetes mellitus were excluded. Data on the women's weights before and at the end of pregnancy were collected during medical examination. A physician measured the heights of the women by using a stadiometer (SECA, Hamburg, Germany) at the time of recruitment. The anthropometric data on weight and length, gestational age, mode of delivery (vaginal or caesarean section), sex, and Apgar score of the new-borns with a perinatal medical history were collected. The pregestational record of smoking (cigarettes) and alcohol consumption were collected from responses to direct questions during the medical examination. According to their smoking history, the women were classified as follows: smokers (smoking women), consumed 1-5 cigarettes per day and stopped smoking during the first trimester of pregnancy (according to the questionnaire), and nonsmokers (non-smoking women), denied direct or indirect tobacco consumption or exposure.

\section{Food frequency questionnaire}


A food frequency questionnaire (FFQ) to assess regular food intake during pregnancy was administered by the medical staff to all the participants. The questionnaire had been validated for estimation of folate intake in the Mexican population [41]. The questionnaire contained 127 food items. As supporting material, the interviewer used food replicas to standardise the types and amounts of the main food groups consumed by the participants. The participants' food intakes per day were estimated, and the amount of food consumed was calculated in terms of the unit of measurement used (e.g. piece, cup, plate, or spoon) and the size of the unit (i.e. small, medium, or large). The frequencies of consumption of the 127 food items were calculated in grams or millilitres ingested per day. The participants' daily intake levels of energy, macronutrients, and micronutrients were calculated using the Food Processor SQL programme (version 10.9.0, 2011; ESHA Research, Salem, Oregon) and Mexican food tables, including data on traditional Mexican food [42]. For the analysis, data cleaning was performed, considering the consumption of energy, macronutrients, and micronutrients $>5$ standard deviations from the average consumptions as not plausible. Amongst the lower values, energy adequacy values $<25 \%$ were eliminated, as adequacy percentages less than that value could not represent intakes compatible with life.

\section{Blood samples}

In the last medical examination before birth, 5-mL peripheral blood samples were collected from the participants. Immediately after birth, the umbilical cord was clamped, and 5-mL blood samples were collected from it. Blood samples were collected in ethylenediaminetetraacetic acid-containing tubes, centrifuged at $1,800 \times \mathrm{g} / 15 \mathrm{~min}$, and subjected to protein precipitation with $20 \%$ trichloroacetic acid (50:50 $\mathrm{V} / \mathrm{V})$. Then, centrifugation was repeated at $3,600 \times \mathrm{g} / 5 \mathrm{~min}$ at $4^{\circ} \mathrm{C}$. Plasma samples were kept at $-80^{\circ} \mathrm{C}$ until $8-\mathrm{OHdG}$ quantification.

\section{8-OHdG quantification}

The 8-OHdG levels were determined in the plasmas, which were deproteinised by immunofluorescence using the 8-hyrdoxy-2'-deoxyguanosine enzyme immunoassay (EIA) kit (CEDERLANE, USA). Briefly, $50 \mu \mathrm{L}$ of deproteinised plasma, the EIA buffer, the 8-hydroxy-2-deoxy Guanosine EIA Standard (Cat\# CL89120KC), and the 8-OHdG-AChE tracer were added to the wells in accordance with the manufacturers' recommendations. The monoclonal antibody 8-OHdG was added, and the plate was incubated for $18 \mathrm{~h}$ at $4^{\circ} \mathrm{C}$ and washed several times with buffer. Then, $200 \mu \mathrm{L}$ of Ellman's reactive was added to each well. The optical density was determined at $405 \mathrm{~nm}$.

\section{DNA placental purification}

$3 \mathrm{~cm}^{2}$ of maternal surface placenta was dissected and washed with sterile $\mathrm{NaCl} 0.9 \%$ solution within the first 10 min after delivery. The samples were stored in conic tubes with $\mathrm{NaCl} 0.9 \%$ and kept at $4^{\circ} \mathrm{C}$ for transportation. Upon arrival of the samples at the laboratory, the samples were stored at $-80^{\circ} \mathrm{C}$ until DNA isolation. DNA purification was performed using the Gentra Puregene Gen kit (QIAGEN, USA) according to the manufacturer's procedure, briefly; 6-10 $\mathrm{mg}$ of placenta were disaggregated, keeping it on ice during the 
procedure; mixed with cell lysis solution, and incubated at $65^{\circ} \mathrm{C} / 15 \mathrm{~min}$, followed by $55^{\circ} \mathrm{C} / 15 \mathrm{~min}$ with Puregene Proteinase $\mathrm{K}$, and $37^{\circ} \mathrm{C} / 15 \mathrm{~min}$ with RNAsa A solution. To each sample, was added protein precipitation solution and centrifuged at $13,000 \times \mathrm{g} / 3 \mathrm{~min}$. The aqueous phase was recovered and added $100 \%$ isopropanol (Sigma-Aldrich, USA). The samples were centrifuged at $13,000 \times \mathrm{g} / 3 \mathrm{~min}$, and the supernatant discarded. The DNA was eluted in an elution solution and incubated at $65^{\circ} \mathrm{C} / 1 \mathrm{~h}$. Finally, the samples were kept at $-80^{\circ} \mathrm{C}$ until they were used for ultra-high performance liquid chromatography coupled with highresolution mass spectrometry (UPLC-HRMS) assays. The purity and concentration of the samples were determined with spectrophotometry at a ratio of A260/A280, and their integrity by electrophoresis.

\section{Enzymatic hydrolysis of DNA}

Placental DNA samples were hydrolysed to obtain free nucleosides [43], briefly; 1-10 $\mu$ g of DNA was eluted in $35 \mu \mathrm{L}$ of water and $5 \mu \mathrm{L}$ of hydrolysis buffer (acetic acid, $200 \mathrm{mM}$; glycine, $200 \mathrm{mM} ; \mathrm{MgCl}_{2}, 50 \mathrm{nM} ; \mathrm{ZnCl}_{2}, 5$ $\mathrm{mM}$; and $\mathrm{CaCl}_{2}, 2 \mathrm{mM}$; pH 5.3) and incubated with $10 \mu \mathrm{L}$ of nuclease mixture ( $1 \mathrm{U}$ of nuclease P1 and $20 \mathrm{U}$ of DNAsa) at $37^{\circ} \mathrm{C} / 14 \mathrm{~h}$. Next, $5 \mu \mathrm{L}$ of $\mathrm{NaOH} 100 \mathrm{mM}$ and $10 \mu \mathrm{L}$ of alkaline phosphatase $(0.2 \mathrm{U} / \mu \mathrm{L})$ were added to the mixture and incubated at $37^{\circ} \mathrm{C} / 2 \mathrm{~h}$. The samples were kept at $-20^{\circ} \mathrm{C}$ until UPLC-HRMS analysis.

\section{Determination of global DNA methylation by UPLC-HRMS}

$\mathrm{dC}$ and $5 \mathrm{mdC}$ were determined using the chromatographic system UPLC Acquity I-class (Waters) coupled with the mass spectrometer Synapt G2-Si (Waters) [44], briefly; $2 \mu \mathrm{L}$ of each hydrolysed sample were injected in an UPLC Luna Omega C18 $100 \AA$ A with a $1.6 \mu \mathrm{m}$ column $(150 \times 2.1 \mathrm{~mm}$; Phenomenex $)$, maintained at $40^{\circ} \mathrm{C}$ at a flow rate of $100 \mu \mathrm{L} / \mathrm{min}$, and eluted with the mobile phases of ammonium formate $10 \mathrm{mM}(\mathrm{pH} 4)(\mathrm{A})$ and methanol (B) in the following gradient programme: 0 to 3 min for $5 \%$ B, 3 to 7.5 min for $20 \%$ B, and 7.5 to 10 min for $5 \%$ B. Free nucleosides were detected using a mass spectrometer by the following operation parameters: electrospray ionisation in positive mode (ESI+); capillary voltage, $3000 \mathrm{~V}$; cone voltage, $30 \mathrm{~V}$; source temperature, $120^{\circ} \mathrm{C}$; desolvation gas, $\mathrm{N}_{2}$; desolvation gas temperature, $350^{\circ} \mathrm{C}$; desolvation gas flow, 800 $\mathrm{L} / \mathrm{h}$; acquisition mass range, $50-600 \mathrm{~m} / \mathrm{z}$; scan time, $0.4 \mathrm{sec}$; and data format, centroid. The analytical signals of the ionic dimers [44]+ at $\mathrm{m} / z 455.19 \pm 0.01 \mathrm{Da}$ and $483.22 \pm 0.01$ were used for $\mathrm{dC}$ and $5 \mathrm{mdC}$ quantification. Global DNA methylation was calculated as the molar ratio of [5 $\mathrm{mdC} /(\mathrm{dC}+5 \mathrm{mdC})]$.

\section{Statistical analyses}

Descriptive statistics, including mean, standard deviation, median, interquartile range, and frequencies, were used to describe the baseline characteristics of mothers and new-borns. A pre-exploratory variable analysis was conducted to identify their distributions. To compare the baseline characteristics between the smoking women and non-smoking women, the continuous variables without a normal distribution in the MannWhitney $U$ test were used. For the continuous variables with a normal distribution (Shapiro-Wilk normality test, $\mathrm{P}>0.05)$, the Student $t$ test was used, and for the categorical variables, the Mann-Whitney $U$ test was used. By using medians and interquartile ranges (IQRs), we report the daily calories obtained from the food consumed; amounts of proteins, carbohydrates, and fats; and the mothers' and new-borns' consumptions of 
vitamins and oxidant levels. Robust regression models were used to evaluate the association of smoking and non-smoking with oxidative levels. Data analysed and plots were constructed using the language $R$ version 3.6.2 (2019-12-12). P values < 0.05 were considered to indicate statistically significant differences.

\section{Results}

\section{Subject characteristics}

The perinatal characteristics of the mothers and the characteristics of the new-borns at birth are shown in Table 1. The mean age did not significantly differ between the non-smoking women and smoking women. Height and pregestational weight or pregestational Body Mass Index (BMI) were not significantly different among the groups. In both groups, multi-vitamin and folic acid supplementations were not significantly different. Alcohol intake was significantly higher in the smoking women than in the nonsmoking women $(p=0.002)$. The new-borns did not significantly differ in weight, height, or gestational age. The new-born's Apgar score, in the first and fifth minute of testing were not significantly different between the groups. However, the Silverman scores were slightly lower in the smoking new-born group $(p=0.049 ;$ Table 1$)$.

\section{Nutritional characteristics of the smoking and non-smoking women}

The evaluation of nutritional status during pregnancy revealed that the smoking women had significantly higher intakes of calories, carbohydrates, lipids, and proteins, and estimated consumptions of vitamin $A$, vitamin B12, vitamin C, vitamin E, and folic acid than the non-smoking women (Table 2).

\section{8-OHdG levels in the groups}

8-OHdG plasmatic levels showed a positive and strong correlation in both mothers and new-borns (Figure 1). In our groups, robust logistic models showed that in the smoking's binomials the proportion of 8-OHdG levels decreased by the end of pregnancy: when we did not adjust the model by any variable (model 1), when we adjusted the model by maternal age, alcohol consumption, gestational age, and pregestational BMI (model 2), or even when we add the kilocalorie intake during the pregnancy (model 3) (Table 3).

\section{Correlation of 8-OHdG level with macronutrients and micronutrients}

Maternal 8-OHdG showed negative correlations with daily consumption of calories, carbohydrates, lipids, proteins, vitamin A, vitamin B12, vitamin E, and folic acid but with vitamin C (Table 4). The new-borns' 8-OHdG levels slightly but significantly correlated with the mothers' daily intakes of proteins, vitamin A, and vitamin 12 but calories, carbohydrates, lipids, vitamin $\mathrm{C}$, vitamin $\mathrm{E}$, or folic acid (Table 4). In addition, the unadjusted model showed that the smoking women had significantly lower 8-OHdG levels, which was still lower after adjustment for maternal age, alcohol consumption, gestational age, and BMI before pregnancy, but not when 
we included the daily calorie intake (Table 3). The unadjusted model showed a tendency to significantly lower the 8-OHdG levels in the smoking women's new-borns (Table 3). When we adjusted for maternal age, alcohol consumption, gestational age, and BMI before pregnancy (Table 3 ) and included daily calorie intake (Table 3), we found significantly lower 8-OHdG levels.

\section{Correlation of cigarette consumption with macronutrient and micronutrients}

Daily cigarette consumption showed a significant negative correlation with the women's 8-OHdG levels and a positive correlation with their daily estimated consumptions of calories, carbohydrates, lipids, proteins, vitamin A, vitamin B12, vitamin C, vitamin E, and folic acid, but not with the new-borns' 8-OHdG levels (Table 5).

\section{Methylated DNA and cigarette consumption}

Since the maternal face of the placenta is more susceptible to the effect of environmental stimuli (e.g. free radicals) [45], we decided to take the samples of it to study the overall level of DNA methylation (metDNA). In this work metDNA correlated significantly with daily cigarette consumption (Figure 2). The proportion of metDNA was significantly lower in the smoking women than in the non-smoking women: The unadjusted model also showed that the smoking women had a significantly lower proportion of metDNA than the nonsmoking women during pregnancy, which remained lower even after adjustment for maternal age, alcohol consumption, gestational age (weeks), and BMI before pregnancy, and when daily calorie intake was included (Table 3).

\section{Correlations of methylated DNA level with 8-OHdG, micronutrient or macronutrient}

Finally, metDNA did not correlate with the women's or new-borns' 8-OHdG levels, or with the daily estimated consumption of calories, carbohydrates, lipids, proteins, vitamin A, vitamin B12, vitamin C, vitamin $E$, or folic acid $(p>0.05)$.

\section{Discussion}

Cigarette smoking is a common practice amongst women of a wide range of ages and social statuses [46]. Unfortunately, the exposure to cigarette smoke has been associated with several diseases $[35,47,48]$ because of their deleterious effects on carbohydrates, lipids, proteins, cellular structures, or DNA [49,50], owing to the enormous quantity of free radicals (FRs) that are produced during cigarette burning. Due to their lower reduction potential, guanines are the main adductor of FRs, and such interaction produces 8-OHdG [36]. 8OHdG level has been used widely as a marker of DNA damage in smokers [51].

As previously mentioned, we determined the plasma levels of 8-OHdG in the mother-child pairs in the smoking and non-smoking groups to determine whether the effect of smoking during the first trimester of pregnancy 
remains until the end of pregnancy. In this work, we detected levels of 8-OHdG in umbilical blood and plasma similar as reported by other authors [52-54], who employed the same methodology. In addition, we found significantly lower 8-OHdG levels in the smoking women group, consistent with previously reported findings $[55,56]$. However, the 8-OHdG levels were significantly lower in the new-borns of the smoking women, contrary to the report of Ebina et al., where the 8-OHdG levels of the new-borns of smoking women were high.

Nevertheless, they did not specify the time of smoking during pregnancy [52], which is important since 8-OHdG higher levels have been observed in active adult smoker $[57,58]$ than in pregnant women $[55,56]$.

In this work, the smoking women displayed significantly higher consumptions of calories, micronutrients, and macronutrients. One reason is that once the women stopped smoking during the first trimester of pregnancy, the cessation of smoking itself could increase food consumption $[59,60]$ in two ways: first, nicotine inhibits food desire, and second, cigarette reward is substituted with food-reward (Table 2) [61]. Even though the higher estimated consumption of micronutrients of the smoking group, several studies have associated lower plasma levels of vitamin A [62, 63], vitamin C [62, 64, 65], vitamin E [62, 63, 65], folic acid, and vitamin B12 [66] with smokers, which could explain the lower global metDNA levels as we have proposed (Figure 3 ). This could be explained by lower absorption rate [67], altered vitamin metabolism [68-70], or increased elimination rate $[68,71]$ in the smoking women group. However, investigating whether the plasma vitamin levels of the smoking women in our study were deficient is beyond the scope of this work.

Owing to the association of overweight and obesity with oxidative stress in adults and pregnant women [72], and oxidative stress with DNA damage [73], we further analysed the nutritional status of the study groups on the basis of their 8-OHdG levels. Thereby, we found no correlation between 8-OHdG and $\mathrm{BMI}(\mathrm{Rho}=0.08, p=$ 0.426), which is in agreement with other studies $[40,56,58,74]$. Nevertheless, we observed that smoking women had greater food intakes than the non-smoking women (Table 2). This behaviour could provide higher amounts of vitamins with protective or preventive effects on 8-OHdG formation in the foetus. In addition, it may explain the significantly lower level of 8-OHdG in the smoking pair (Table 3), and the inverse correlation of vitamins with antioxidant potential and the 8-OHdG levels (Table 4). On the other hand, we cannot discard the possibility that 8-OHdG works antioxidant in smoking binomials [75], or be due to a buffering effect of the placenta [76-78], which could be additional explanations of the lower levels detected in our smoking binomials.

8-OHdG is a modified nucleotide product of the interaction between guanines and FRs and owing to its structure, 8-OHdG more easily pairs with thymine than with cytosine during DNA replication or deficient repair reversion $[36,73,79]$. The transversion or $8-\mathrm{OHdG}$ expression itself in $\mathrm{CpG}$ islands (CpGIs) can inhibit the methylation by DNA methyl-transferase $3 a[80,81]$ or $3 b$ [82]. Human genomes up to $60 \%$ of the CpGls are located in gene promotors [83] of which $80 \%$ are associated with gene expression because cytosine methylation suppresses or decreases gene expression $[84,85]$.

The placenta connects the child to the mother for imperative functions, including nutritional support, waste elimination, gas transference, hormone secretion and synthesis, immune tolerance to the product, and acts as a barrier against pathogenic agents [86]. Thus, placenta study is important for understanding the mechanisms of deleterious agents. We assessed the overall metDNA percentage on the basis of its association with 8OHdG and metDNA levels (Figure 3). We found a negative correlation between the percentage of metDNA and 
the number of cigarettes consumed per day, which could be due to the mechanism we described earlier [87]. Our study was different from other studies that aimed to identify specific differential methylated CpGIs in the placentas of smoking women [29, 88-91]. In this study we observed a significantly lower global methylation status in the placenta. However, other studies did not take into consideration nutritional status, it is important because nutritional status can modify metDNA patterns [92]. One plausible explanation of the oxidative stressinduced significant decrease in metDNA level in the smokers could be that the saturation levels of the antioxidant enzymatic systems such as the superoxide dismutase (SOD) enzyme activities, which is one of the most important antioxidant systems [93], were decreased in smokers as compared with non-smokers [94, 95]. Although, the SOD levels of smokers were normal [96], the levels of their cofactors were high [94]. The cofactors, together with reactive oxygen species, nitric oxide synthase, and metals from tobacco smoke [97, 98], could inhibit SOD enzyme activities in smokers. Although, several studies report that consumption of $\geq 10$ cigarettes per day have deep effects [40,58,99], we found biological effects of consuming 1 to 5 cigarettes per day until late pregnancy even though women stopped smoking during the first trimester of pregnancy. However, we found that the mothers' and new-borns' DNA damage maker levels (8-OHdG) showed no significant correlations with the percentage of metDNA $(p>0.05)$.

Lastly, studies on epigenetic changes induced by cigarette smoking have associated these changes with the development of several diseases (Figure 3). Therefore, studying the epigenome in new-borns exposed to cigarette smoke in early life stages, even without any pathological evidence, could be useful for identifying new-borns at higher risk of the aforementioned conditions and for establishing preventive health programs focusing on this population.

Limitations: First, we cannot assure women stop smoking during the first trimester of pregnancy since we can only take into consideration what they mentioned during the interview. Second, because of the cross-sectional design of this study, it is hard to determine the levels of $8-\mathrm{OHdG}$ at begin of pregnancy. Third, due to vitamins estimation was determined by the query, it is hard to estimate a direct link among them and the levels of 8OHdG. Last, we did not have record of the men smoking history since paternal smoking has been associated with health affectations in the offspring [100] .

\section{Conclusions}

We found an inverse association between 8-OHdG concentrations and smoking in the first trimester of pregnancy which could be explained by smoking cessation. Which consequently causes an increase in the consumption of food for the rest of the pregnancy. Cigarette consumption during the first trimester of pregnancy was significantly associated with global DNA methylation changes at the end of pregnancy via 8$\mathrm{OHdG}$ synthesis. Even though the clinical phenotypes of offspring are normal at delivery, the effects of cigarette smoking could appear over the years and even trans-generationally [101].

\section{Abbreviations}

8-OHdG: 8-hydroxy-2'deoxyguanosine.

MetDNA: Methylated DNA. 
OS: Oxidative stress.

FR: Free radicals.

\section{Declarations}

\section{Ethics approval and consent to participate}

After being explained about the goal of this study all pregnant women signed the written informed consent. This study was conducted in accordance with the latest version of the principles of the Declaration of Helsinki and the protocol was approved by the committees for the investigation, Ethics and Biosecurity from Hospital Infantil de Mexico Federico Gómez (HIM 2016-031).

\section{Consent for publication}

Does not apply.

\section{Availability of data and materials}

The dataset of the raw data used in this study is available in Supplementary file 1. It is disposable for other researches under proper reference.

\section{Competing interests}

The authors declare do not have competing interests.

\section{Funding}

This study was funded by an internal grant at Hospital Infantil de Mexico Federico Gómez, Mexico (grant number: HIM 2016-031).

\section{Authors' contributions}

RSU conceived the research, carried out the analyses to obtain results, collaborated with the assembly of the first draft of the manuscript and incorporated the suggestions of co-authors. HDG carried out experimental work and developed data analysis and interpretation, and the first draft manuscript. JGL carried out experimental work and sample collection. KVCC and ALT carried out experimental work and data analyses. JVG and MKK developed experimental design and data analyses. PGR carried out experimental work and data analyses. JTGR design of the project and data interpretation. All authors collaborated to the writing, and have read and approved the final manuscript. 


\section{Acknowledgements}

The author H. Diaz-Garcia thanks the support receive by the Programa Nacional de Posgrados de Calidad (PNPC) of CONACyT Mexico (grant number: 420044), and by the Beca de Estímulo Institucional de Formación de Investigadores (BEIFI) program from the Instituto Politécnico Nacional (Mexico).

The authors thank to the Direction Unit of Research of Hospital Infantil of Mexico, Federico Gómez for their support this study.

\section{References}

1. Smoking prevalence and attributable disease burden in 195 countries and territories, 1990-2015: a systematic analysis from the Global Burden of Disease Study 2015. Lancet (London, England). 2017;389(10082):1885-906. doi: 10.1016/s0140-6736(17)30819-x.

2. Jha P. Avoidable global cancer deaths and total deaths from smoking. Nature Reviews Cancer. 2009;9(9):655-64. doi: 10.1038/nrc2703.

3. Reynales- Shigematsu LM. Zavala-Arciniega L P-BW, Gutiérrez-Torres DS G-BJ, Rodriguez-Andrade MA, Gutiérrez-Reyes, J., Franco-Núñez, A., Romero-Martínez MyM-A, L.. Encuesta Nacional de Consumo de Drogas, Alcohol y Tabaco 2016-2017: Reporte de Tabaco.. In: Instituto Nacional de Psiquiatría Ramón de la Fuente Muñiz; Instituto Nacional de Salud Pública C, Nacional Contra las Adicciones SdS, editors. Instituto Nacional de Psiquiatría Ramón de la Fuente Muñiz; Instituto Nacional de Salud Pública, Comisión Nacional Contra las Adicciones, Secretaría de Salud Ciudad de México, México: INPRFM; 2017.2017.

4. McEvoy CT, Spindel ER. Pulmonary Effects of Maternal Smoking on the Fetus and Child: Effects on Lung Development, Respiratory Morbidities, and Life Long Lung Health. Paediatric respiratory reviews. 2017;21:27-33. doi: 10.1016/j.prrv.2016.08.005.

5. Vickers MH. Early life nutrition, epigenetics and programming of later life disease. Nutrients. 2014;6(6):2165-78. doi: 10.3390/nu6062165.

6. Desai M, Jellyman JK, Ross MG. Epigenomics, gestational programming and risk of metabolic syndrome. International journal of obesity (2005). 2015;39(4):633-41. doi: 10.1038/ijo.2015.13.

7. Ruchat SM, Houde AA, Voisin G, St-Pierre J, Perron P, Baillargeon JP, et al. Gestational diabetes mellitus epigenetically affects genes predominantly involved in metabolic diseases. Epigenetics. 2013;8(9):93543. doi: 10.4161/epi.25578.

8. Gagné-Ouellet V, Houde AA, Guay SP. Placental lipoprotein lipase DNA methylation alterations are associated with gestational diabetes and body composition at 5 years of age. 2017;12(8):616-25. doi: 10.1080/15592294.2017.1322254.

9. Miyake K, Miyashita C, Ikeda-Araki A, Miura R, Itoh S, Yamazaki K, et al. DNA methylation of GFI1 as a mediator of the association between prenatal smoking exposure and ADHD symptoms at 6 years: the Hokkaido Study on Environment and Children's Health. Clinical epigenetics. 2021;13(1):74. doi: 10.1186/s13148-021-01063-z. 
10. Küpers LK, Xu X, Jankipersadsing SA, Vaez A, la Bastide-van Gemert S, Scholtens S, et al. DNA methylation mediates the effect of maternal smoking during pregnancy on birthweight of the offspring. Int J Epidemiol. 2015;44(4):1224-37. doi: 10.1093/ije/dyv048.

11. Sarkar DK, Gangisetty O, Wozniak JR, Eckerle JK, Georgieff MK, Foroud TM, et al. Persistent Changes in Stress-Regulatory Genes in Pregnant Women or Children Exposed Prenatally to Alcohol. 2019;43(9):1887-97. doi: 10.1111/acer.14148.

12. Breton-Larrivée M, Elder E, McGraw S. DNA methylation, environmental exposures and early embryo development. 2019;16(3):465-74. doi: 10.21451/1984-3143-ar2019-0062.

13. Nabet C, Ancel PY, Burguet A, Kaminski M. Smoking during pregnancy and preterm birth according to obstetric history: French national perinatal surveys. Paediatr Perinat Epidemiol. 2005;19(2):88-96. doi: 10.1111/j.1365-3016.2005.00639.x.

14. Kyrklund-Blomberg NB, Granath F, Cnattingius S. Maternal smoking and causes of very preterm birth. Acta obstetricia et gynecologica Scandinavica. 2005;84(6):572-7. doi: 10.1111/j.0001-6349.2005.00848.x.

15. Steyn K, de Wet T, Saloojee Y, Nel H, Yach D. The influence of maternal cigarette smoking, snuff use and passive smoking on pregnancy outcomes: the Birth To Ten Study. Paediatr Perinat Epidemiol. 2006;20(2):90-9. doi: 10.1111/j.1365-3016.2006.00707.x.

16. Alverson CJ, Strickland MJ, Gilboa SM, Correa A. Maternal smoking and congenital heart defects in the Baltimore-Washington Infant Study. Pediatrics. 2011;127(3):e647-53. doi: 10.1542/peds.2010-1399.

17. García-Villarino M, Fernández-Iglesias R. Prenatal Exposure to Cigarette Smoke and Anogenital Distance at 4 Years in the INMA-Asturias Cohort. 2021;18(9). doi: 10.3390/ijerph18094774.

18. Zlotkowska R, Zejda JE. Fetal and postnatal exposure to tobacco smoke and respiratory health in children. European journal of epidemiology. 2005;20(8):719-27. doi: 10.1007/s10654-005-0033-z.

19. Lannerö E, Wickman M, Pershagen G, Nordvall L. Maternal smoking during pregnancy increases the risk of recurrent wheezing during the first years of life (BAMSE). Respiratory research. 2006;7(1):3. doi: 10.1186/1465-9921-7-3.

20. Bjerg A, Hedman L, Perzanowski M, Lundbäck B, Rönmark E. A strong synergism of low birth weight and prenatal smoking on asthma in schoolchildren. Pediatrics. 2011;127(4):e905-12. doi: 10.1542/peds.20102850.

21. Taylor B, Wadsworth J. Maternal smoking during pregnancy and lower respiratory tract illness in early life. Arch Dis Child. 1987;62(8):786-91. doi: 10.1136/adc.62.8.786.

22. Ekblad M, Lehtonen L, Korkeila J, Gissler M. Maternal Smoking During Pregnancy and the Risk of Psychiatric Morbidity in Singleton Sibling Pairs. Nicotine \& tobacco research: official journal of the Society for Research on Nicotine and Tobacco. 2017;19(5):597-604. doi: 10.1093/ntr/ntx001.

23. Sourander A, Sucksdorff M, Chudal R, Surcel HM, Hinkka-Yli-Salomäki S, Gyllenberg D, et al. Prenatal Cotinine Levels and ADHD Among Offspring. Pediatrics. 2019;143(3). doi: 10.1542/peds.2018-3144.

24. Kovess V, Keyes KM, Hamilton A, Pez O, Bitfoi A, Koç C, et al. Maternal smoking and offspring inattention and hyperactivity: results from a cross-national European survey. European child \& adolescent psychiatry. 2015;24(8):919-29. doi: 10.1007/s00787-014-0641-9. 
25. Brannigan R, Tanskanen A, Huttunen MO, Cannon M, Leacy FP, Clarke MC. Maternal smoking during pregnancy and offspring psychiatric disorder: a longitudinal birth cohort study. Social psychiatry and psychiatric epidemiology. 2021. doi: 10.1007/s00127-021-02094-w.

26. Guerrero-Preston R, Goldman LR, Brebi-Mieville P, Ili-Gangas C, Lebron C, Witter FR, et al. Global DNA hypomethylation is associated with in utero exposure to cotinine and perfluorinated alkyl compounds. Epigenetics. 2010;5(6):539-46. doi: 10.4161/epi.5.6.12378.

27. Murphy SK, Adigun A, Huang Z, Overcash F, Wang F, Jirtle RL, et al. Gender-specific methylation differences in relation to prenatal exposure to cigarette smoke. Gene. 2012;494(1):36-43. doi: 10.1016/j.gene.2011.11.062.

28. Breton CV, Byun HM, Wenten M, Pan F, Yang A, Gilliland FD. Prenatal tobacco smoke exposure affects global and gene-specific DNA methylation. American journal of respiratory and critical care medicine. 2009;180(5):462-7. doi: 10.1164/rccm.200901-01350C.

29. Rousseaux S, Seyve E, Chuffart F, Bourova-Flin E, Benmerad M, Charles M-A, et al. Immediate and durable effects of maternal tobacco consumption alter placental DNA methylation in enhancer and imprinted gene-containing regions. BMC Medicine. 2020;18(1):306. doi: 10.1186/s12916-020-01736-1.

30. Chavira-Suárez E, Ramírez-Mendieta AJ, Martínez-Gutiérrez S, Zárate-Segura P. Influence of pre-pregnancy body mass index (p-BMI) and gestational weight gain (GWG) on DNA methylation and protein expression of obesogenic genes in umbilical vein. 2019;14(12):e0226010. doi: 10.1371/journal.pone.0226010.

31. Nomura Y, Lambertini L, Rialdi A, Lee M, Mystal EY, Grabie M, et al. Global Methylation in the Placenta and Umbilical Cord Blood From Pregnancies With Maternal Gestational Diabetes, Preeclampsia, and Obesity. Reproductive Sciences. 2014;21(1):131-7. doi: 10.1177/1933719113492206.

32. Zhao BH, Jiang Y, Zhu H, Xi FF, Chen Y, Xu YT, et al. Placental Delta-Like 1 Gene DNA Methylation Levels Are Related to Mothers' Blood Glucose Concentration. 2019;2019:9521510. doi: 10.1155/2019/9521510.

33. Reichetzeder C, Dwi Putra SE, Pfab T, Slowinski T, Neuber C, Kleuser B, et al. Increased global placental DNA methylation levels are associated with gestational diabetes. Clin Epigenetics. 2016;8:82. doi: 10.1186/s13148-016-0247-9.

34. Vadhanam MV, Thaiparambil J, Gairola CG, Gupta RC. Oxidative DNA Adducts Detected in Vitro from Redox Activity of Cigarette Smoke Constituents. Chemical Research in Toxicology. 2012;25(11):2499504. doi: $10.1021 /$ tx300312f.

35. Pryor WA. Cigarette smoke radicals and the role of free radicals in chemical carcinogenicity. Environ Health Perspect. 1997;105 Suppl 4(Suppl 4):875-82. doi: 10.1289/ehp.97105s4875.

36. Cadet J, Wagner JR, Shafirovich V, Geacintov NE. One-electron oxidation reactions of purine and pyrimidine bases in cellular DNA. Int J Radiat Biol. 2014;90(6):423-32. doi:

10.3109/09553002.2013.877176.

37. Pfeifer GP, Hainaut P. On the origin of $G \rightarrow T$ transversions in lung cancer. Mutation Research/Fundamental and Molecular Mechanisms of Mutagenesis. 2003;526(1):39-43. doi: https://doi.org/10.1016/S00275107(03)00013-7.

38. Asami S, Manabe H, Miyake J, Tsurudome Y, Hirano T, Yamaguchi R, et al. Cigarette smoking induces an increase in oxidative DNA damage, 8-hydroxydeoxyguanosine, in a central site of the human lung. Carcinogenesis. 1997;18(9):1763-6. doi: 10.1093/carcin/18.9.1763. 
39. Zeilinger S, Kühnel B, Klopp N, Baurecht H, Kleinschmidt A, Gieger C, et al. Tobacco Smoking Leads to Extensive Genome-Wide Changes in DNA Methylation. PLoS One. 2013;8(5):e63812. doi:

10.1371/journal.pone.0063812.

40. Tamae K, Kawai K, Yamasaki S, Kawanami K, Ikeda M, Takahashi K, et al. Effect of age, smoking and other lifestyle factors on urinary 7-methylguanine and 8-hydroxydeoxyguanosine. Cancer science. 2009;100(4):715-21. doi: 10.1111/j.1349-7006.2009.01088.x.

41. Galván-Portillo M, Torres-Sánchez L, Hernández-Ramírez RU, Anaya-Loyola MA. [Validity and reproducibility of a food frequency questionnaire to estimate folate intake in a Mexican population]. Salud publica de Mexico. 2011;53(3):237-46. doi: 10.1590/s0036-36342011000300008.

42. Pérez LAB PG, Castro BAL. Sistema Mexicano de Alimentos Equivalentes. 3 ed. México: Fomento de Nutrición y Salud; 2008.

43. Rozhon W, Baubec T, Mayerhofer J, Mittelsten Scheid O, Jonak C. Rapid quantification of global DNA methylation by isocratic cation exchange high-performance liquid chromatography. Analytical biochemistry. 2008;375(2):354-60. doi: 10.1016/j.ab.2008.01.001.

44. Alcazar Magana A, Wrobel K. Application of liquid chromatography/electrospray ionization ion trap tandem mass spectrometry for the evaluation of global nucleic acids: methylation in garden cress under exposure to CuO nanoparticles. 2016;30(1):209-20. doi: 10.1002/rcm.7440.

45. Fortier AL, Lopes FL, Darricarrère N, Martel J, Trasler JM. Superovulation alters the expression of imprinted genes in the midgestation mouse placenta. Human molecular genetics. 2008;17(11):1653-65. doi: $10.1093 / \mathrm{hmg} / \mathrm{ddn} 055$.

46. Jafari A, Rajabi A, Gholian-Aval M, Peyman N, Mahdizadeh M, Tehrani H. National, regional, and global prevalence of cigarette smoking among women/females in the general population: a systematic review and meta-analysis. Environmental Health and Preventive Medicine. 2021;26(1):5. doi: 10.1186/s12199020-00924-y.

47. (CDC) CfDCaP: Health Effects of Cigarette Smoking.

https://www.cdc.gov/tobacco/data_statistics/fact_sheets/health_effects/effects_cig_smoking/index.htm (2020). Accessed June 11th, 20212021.

48. Pryor WA, Prier DG, Church DF. Electron-spin resonance study of mainstream and sidestream cigarette smoke: nature of the free radicals in gas-phase smoke and in cigarette tar. Environ Health Perspect. 1983;47:345-55. doi: 10.1289/ehp.8347345.

49. Cantin AM. Cellular Response to Cigarette Smoke and Oxidants. Proceedings of the American Thoracic Society. 2010;7(6):368-75. doi: 10.1513/pats.201001-014AW.

50. Lobo V, Patil A, Phatak A, Chandra N. Free radicals, antioxidants and functional foods: Impact on human health. Pharmacogn Rev. 2010;4(8):118-26. doi: 10.4103/0973-7847.70902.

51. Cao C, Lai T, Li M, Zhou H, Lv D, Deng Z, et al. Smoking-promoted oxidative DNA damage response is highly correlated to lung carcinogenesis. Oncotarget. 2016;7(14):18919-26. doi:

10.18632/oncotarget.7810.

52. Ebina S, Chiba T, Ozaki T, Kashiwakura I. Relationship between 8-hydroxydeoxyguanosine levels in placental/umbilical cord blood and maternal/neonatal obstetric factors. Experimental and therapeutic medicine. 2012;4(3):387-90. doi: 10.3892/etm.2012.617. 
53. Stadem PS, Hilgers MV, Bengo D, Cusick SE, Ndidde S, Slusher TM, et al. Markers of oxidative stress in umbilical cord blood from G6PD deficient African newborns. 2017;12(2):e0172980. doi: 10.1371/journal.pone.0172980.

54. Seven A, Güzel S, Aslan M, Hamuryudan V. Lipid, protein, DNA oxidation and antioxidant status in rheumatoid arthritis. Clinical biochemistry. 2008;41(7-8):538-43. doi:

10.1016/j.clinbiochem.2008.01.029.

55. Kawasaki Y, Li Y-S, Ootsuyama Y, Nagata K, Yamato H, Kawai K. Effects of smoking cessation on biological monitoring markers in urine. Genes and Environment. 2020;42(1):26. doi: 10.1186/s41021-02000165-z.

56. Oba S, Inaba Y, Shibuya T, Oshima J, Seyama K, Kobayashi T, et al. Changes in oxidative stress levels during two weeks of smoking cessation treatment and their association with nutritional characteristics in Japanese smokers. Experimental and therapeutic medicine. 2019;17(4):2757-64. doi: 10.3892/etm.2019.7252.

57. Graille M, Wild P, Sauvain J-J, Hemmendinger M, Guseva Canu I, Hopf NB. Urinary 8-OHdG as a Biomarker for Oxidative Stress: A Systematic Literature Review and Meta-Analysis. Int J Mol Sci. 2020;21(11):3743. doi: 10.3390/ijms21113743.

58. Black C, Bot M, Scheffer P, Penninx BW. Sociodemographic and Lifestyle Determinants of Plasma Oxidative Stress Markers 8-OHdG and F2-Isoprostanes and Associations with Metabolic Syndrome. Oxidative Medicine and Cellular Longevity. 2016;2016. doi: 10.1155/2016/7530820.

59. Audrain-McGovern J, Benowitz NL. Cigarette smoking, nicotine, and body weight. Clin Pharmacol Ther. 2011;90(1):164-8. doi: 10.1038/clpt.2011.105.

60. Dallongeville J, Marécaux N, Fruchart JC, Amouyel P. Cigarette smoking is associated with unhealthy patterns of nutrient intake: a meta-analysis. The Journal of nutrition. 1998;128(9):1450-7. doi: 10.1093/jn/128.9.1450.

61. Harris KK, Zopey M, Friedman TC. Metabolic effects of smoking cessation. Nat Rev Endocrinol. 2016;12(5):299-308. doi: 10.1038/nrendo.2016.32.

62. Polidori MC, Mecocci P, Stahl W, Sies H. Cigarette smoking cessation increases plasma levels of several antioxidant micronutrients and improves resistance towards oxidative challenge. The British journal of nutrition. 2003;90(1):147-50. doi: 10.1079/bjn2003890.

63. Bashar SK, Mitra AK. Effect of smoking on vitamin A, vitamin E, and other trace elements in patients with cardiovascular disease in Bangladesh: a cross-sectional study. Nutr J. 2004;3:18-. doi: 10.1186/14752891-3-18.

64. Schectman G, Byrd JC, Gruchow HW. The influence of smoking on vitamin C status in adults. Am J Public Health. 1989;79(2):158-62. doi: 10.2105/ajph.79.2.158.

65. Karademirci M, Kutlu R, Kilinc I. Relationship between smoking and total antioxidant status, total oxidant status, oxidative stress index, vit C, vit E. The clinical respiratory journal. 2018;12(6):2006-12. doi: 10.1111/crj.12757.

66. Tuenter A, Bautista Nino PK, Vitezova A, Pantavos A, Bramer WM, Franco OH, et al. Folate, vitamin B12, and homocysteine in smoking-exposed pregnant women: A systematic review. Maternal \& child nutrition. 2019;15(1):e12675. doi: 10.1111/mcn.12675.

Page $15 / 28$ 
67. Krall EA, Dawson-Hughes B. Smoking increases bone loss and decreases intestinal calcium absorption. Journal of bone and mineral research: the official journal of the American Society for Bone and Mineral Research. 1999;14(2):215-20. doi: 10.1359/jbmr.1999.14.2.215.

68. Linnell JC, Smith AD, Smith CL, Wilson J, Matthews DM. Effects of smoking on metabolism and excretion of vitamin B12. Br Med J. 1968;2(5599):215-6. doi: 10.1136/bmj.2.5599.215.

69. Brot C, Jorgensen NR, Sorensen $\mathrm{OH}$. The influence of smoking on vitamin D status and calcium metabolism. European journal of clinical nutrition. 1999;53(12):920-6. doi: 10.1038/sj.ejcn.1600870.

70. Sealey WM, Teague AM, Stratton SL, Mock DM. Smoking accelerates biotin catabolism in women. The American Journal of Clinical Nutrition. 2004;80(4):932-5. doi: 10.1093/ajcn/80.4.932.

71. Bruno RS, Ramakrishnan R, Montine TJ, Bray TM, Traber MG. a-Tocopherol disappearance is faster in cigarette smokers and is inversely related to their ascorbic acid status. The American Journal of Clinical Nutrition. 2005;81(1):95-103. doi: 10.1093/ajcn/81.1.95.

72. Gallardo JM, Gómez-López J, Medina-Bravo P, Juárez-Sánchez F, Contreras-Ramos A, Galicia-Esquivel M, et al. Maternal obesity increases oxidative stress in the newborn. Obesity (Silver Spring, Md). 2015;23(8):1650-4. doi: 10.1002/oby.21159.

73. Cooke MS, Evans MD, Dizdaroglu M, Lunec J. Oxidative DNA damage: mechanisms, mutation, and disease. Faseb j. 2003;17(10):1195-214. doi: 10.1096/fj.02-0752rev.

74. Sakano N, Wang D-H, Takahashi N, Wang B, Sauriasari R, Kanbara S, et al. Oxidative stress biomarkers and lifestyles in Japanese healthy people. J Clin Biochem Nutr. 2009;44(2):185-95. doi: 10.3164/jcbn.08252.

75. Choi S, Choi HH, Lee SH, Ko SH, You HJ, Ye SK, et al. Anti-inflammatory effects of 8-hydroxy-2'deoxyguanosine on lipopolysaccharide-induced inflammation via Rac suppression in Balb/c mice. Free radical biology \& medicine. 2007;43(12):1594-603. doi: 10.1016/j.freeradbiomed.2007.08.022.

76. Vuppaladhadiam L, Lager J, Fiehn O. Human Placenta Buffers the Fetus from Adverse Effects of Perceived Maternal Stress. 2021;10(2). doi: 10.3390/cells10020379.

77. Thayer ZM, Rutherford J, Kuzawa CW. The Maternal Nutritional Buffering Model: an evolutionary framework for pregnancy nutritional intervention. Evolution, Medicine, and Public Health. 2020;2020(1):14-27. doi: 10.1093/emph/eoz037.

78. Mueller A, Koebnick C, Binder H, Hoffmann I, Schild RL, Beckmann MW, et al. Placental defence is considered sufficient to control lipid peroxidation in pregnancy. Medical Hypotheses. 2005;64(3):553-7. doi: https://doi.org/10.1016/j.mehy.2004.08.008.

79. Shibutani S, Takeshita M, Grollman AP. Insertion of specific bases during DNA synthesis past the oxidation-damaged base 8-oxodG. Nature. 1991;349(6308):431-4. doi: 10.1038/349431a0.

80. Maltseva DV, Baykov AA, Jeltsch A, Gromova ES. Impact of 7,8-dihydro-8-oxoguanine on methylation of the CpG site by Dnmt3a. Biochemistry. 2009;48(6):1361-8. doi: 10.1021/bi801947f.

81. Turk PW, Laayoun A, Smith SS, Weitzman SA. DNA adduct 8-hydroxyl-2'-deoxyguanosine (8hydroxyguanine) affects function of human DNA methyltransferase. Carcinogenesis. 1995;16(5):1253-5. doi: 10.1093/carcin/16.5.1253. 
82. Wei D, Loeken MR. Increased DNA methyltransferase 3b (Dnmt3b)-mediated CpG island methylation stimulated by oxidative stress inhibits expression of a gene required for neural tube and neural crest development in diabetic pregnancy. Diabetes. 2014;63(10):3512-22. doi: 10.2337/db14-0231.

83. Antequera F. Structure, function and evolution of $\mathrm{CpG}$ island promoters. Cellular and molecular life sciences: CMLS. 2003;60(8):1647-58. doi: 10.1007/s00018-003-3088-6.

84. Valinluck V, Tsai H-H, Rogstad DK, Burdzy A, Bird A, Sowers LC. Oxidative damage to methyl-CpG sequences inhibits the binding of the methyl-CpG binding domain (MBD) of methyl-CpG binding protein 2 (MeCP2). Nucleic Acids Res. 2004;32(14):4100-8. doi: 10.1093/nar/gkh739.

85. Lister R, Pelizzola M, Dowen RH, Hawkins RD, Hon G, Tonti-Filippini J, et al. Human DNA methylomes at base resolution show widespread epigenomic differences. Nature. 2009;462(7271):315-22. doi: $10.1038 /$ nature08514.

86. Maccani JZ, Maccani MA. Altered placental DNA methylation patterns associated with maternal smoking: current perspectives. Adv Genomics Genet. 2015;2015(5):205-14. doi: 10.2147/AGG.S61518.

87. Valavanidis A, Vlachogianni T, Fiotakis K. Tobacco smoke: involvement of reactive oxygen species and stable free radicals in mechanisms of oxidative damage, carcinogenesis and synergistic effects with other respirable particles. Int J Environ Res Public Health. 2009;6(2):445-62. doi: 10.3390/ijerph6020445.

88. Suter M, Ma J, Harris A, Patterson L, Brown KA, Shope C, et al. Maternal tobacco use modestly alters correlated epigenome-wide placental DNA methylation and gene expression. Epigenetics. 2011;6(11):1284-94. doi: 10.4161/epi.6.11.17819.

89. Morales E, Vilahur N, Salas LA, Motta V, Fernandez MF, Murcia M, et al. Genome-wide DNA methylation study in human placenta identifies novel loci associated with maternal smoking during pregnancy. International journal of epidemiology. 2016;45(5):1644-55. doi: 10.1093/ije/dyw196.

90. Wilhelm-Benartzi CS, Houseman EA, Maccani MA, Poage GM, Koestler DC, Langevin SM, et al. In utero exposures, infant growth, and DNA methylation of repetitive elements and developmentally related genes in human placenta. Environ Health Perspect. 2012;120(2):296-302. doi: 10.1289/ehp.1103927.

91. Fa S, Larsen TV, Bilde K, Daugaard TF, Ernst EH, Olesen RH, et al. Assessment of global DNA methylation in the first trimester fetal tissues exposed to maternal cigarette smoking. Clinical Epigenetics. 2016;8(1):128. doi: 10.1186/s13148-016-0296-0.

92. Andraos S, de Seymour JV, O'Sullivan JM, Kussmann M. The Impact of Nutritional Interventions in Pregnant Women on DNA Methylation Patterns of the Offspring: A Systematic Review. Molecular Nutrition \& Food Research. 2018;62(24):1800034. doi: https://doi.org/10.1002/mnfr.201800034.

93. Wang Y, Branicky R, Noë A, Hekimi S. Superoxide dismutases: Dual roles in controlling ROS damage and regulating ROS signaling. 2018;217(6):1915-28. doi: 10.1083/jcb.201708007.

94. Pizent A, Lazarus M, Kovačić J, Tariba Lovaković B, Brčić Karačonji I, Živković Semren T, et al. Cigarette Smoking during Pregnancy: Effects on Antioxidant Enzymes, Metallothionein and Trace Elements in Mother-Newborn Pairs. Biomolecules. 2020;10(6):892. doi: 10.3390/biom10060892.

95. Basant Joshi SS, Preeti Sharma, Tapan Mohapatra, Pradeep Kumar. Effect of Cigarette Smoking on Selected Antioxidant Enzymes and Oxidative Stress Biomarkers. Journal of Clinical and Diagnostic Research. 2020;14(10):BC19-BC23. doi: 10.7860/jcdr/2020/45948.14138. 
96. Sidle EH, Casselman R, Smith GN. Effect of cigarette smoke on placental antioxidant enzyme expression. American journal of physiology Regulatory, integrative and comparative physiology. 2007;293(2):R754-8. doi: 10.1152/ajpregu.00505.2006.

97. Humans IWGotEoCRt. Tobacco smoke and involuntary smoking. IARC Monogr Eval Carcinog Risks Hum. 2004;83:1-1438.

98. Ma XD, D.; Chen, W. Inhibitors and Activators of SOD, GSH-Px, and CAT. Croatia: 2017.

99. Wu T, Buck G, Mendola P. Maternal cigarette smoking, regular use of multivitamin/mineral supplements, and risk of fetal death: the 1988 National Maternal and Infant Health Survey. American journal of epidemiology. 1998;148(2):215-21. doi: 10.1093/oxfordjournals.aje.a009626.

100. Li J, Tsuprykov O, Yang X, Hocher B. Paternal programming of offspring cardiometabolic diseases in later life. Journal of hypertension. 2016;34(11):2111-26. doi: 10.1097/hjh.0000000000001051.

101. Youngson NA, Whitelaw E. Transgenerational epigenetic effects. Annual review of genomics and human genetics. 2008;9:233-57. doi: 10.1146/annurev.genom.9.081307.164445.

102. Alberts B JA, Lewis J, et al. DNA Replication Mechanisms. In: Molecular Biology of the Cell. 2021. 4th ed. New York: Garland Science. 2002. https://www.ncbi.nlm.nih.gov/books/NBK26850/.

103. Gajewski E, Rao G, Nackerdien Z, Dizdaroglu M. Modification of DNA bases in mammalian chromatin by radiation-generated free radicals. Biochemistry. 1990;29(34):7876-82. doi: 10.1021/bi00486a014.

104. Kimsey IJ, Szymanski ES, Zahurancik WJ, Shakya A, Xue Y, Chu C-C, et al. Dynamic basis for dG·dT misincorporation via tautomerization and ionization. Nature. 2018;554(7691):195-201. doi: 10.1038/nature25487.

105. Razin A, Riggs A. DNA methylation and gene function. Science. 1980;210(4470):604-10. doi: $10.1126 /$ science.6254144.

106. Saarni SE, Pietiläinen K, Kantonen S, Rissanen A, Kaprio J. Association of smoking in adolescence with abdominal obesity in adulthood: a follow-up study of 5 birth cohorts of Finnish twins. Am J Public Health. 2009;99(2):348-54. doi: 10.2105/AJPH.2007.123851.

107. Akash MSH, Rehman K, Liaqat A. Tumor Necrosis Factor-Alpha: Role in Development of Insulin Resistance and Pathogenesis of Type 2 Diabetes Mellitus. Journal of cellular biochemistry. 2018;119(1):105-10. doi: 10.1002/jcb.26174.

108. Sullivan KE, Reddy AB, Dietzmann K, Suriano AR, Kocieda VP, Stewart M, et al. Epigenetic regulation of tumor necrosis factor alpha. Molecular and cellular biology. 2007;27(14):5147-60. doi:

10.1128/mcb.02429-06.

109. Kobashi C, Asamizu S, Ishiki M, Iwata M, Usui I, Yamazaki K, et al. Inhibitory effect of IL-8 on insulin action in human adipocytes via MAP kinase pathway. J Inflamm (Lond). 2009;6:25-. doi: 10.1186/1476-9255-625.

110. Yoo KH, Park Y-K, Chang S-G. DNA hypomethylation of interleukin 8 in clear cell renal cell carcinoma. Oncol Lett. 2013;5(1):39-42. doi: 10.3892/ol.2012.992.

111. Rotter V, Nagaev I, Smith U. Interleukin-6 (IL-6) induces insulin resistance in 3T3-L1 adipocytes and is, like IL-8 and tumor necrosis factor-alpha, overexpressed in human fat cells from insulin-resistant subjects. The Journal of biological chemistry. 2003;278(46):45777-84. doi: 10.1074/jbc.M301977200. 
112. Zuo HP, Guo YY, Che L, Wu XZ. Hypomethylation of Interleukin-6 Promoter is Associated with the Risk of Coronary Heart Disease. Arquivos brasileiros de cardiologia. 2016;107(2):131-6. doi: 10.5935/abc.20160124.

113. Wren JD, Garner HR. Data-mining analysis suggests an epigenetic pathogenesis for type 2 diabetes. J Biomed Biotechnol. 2005;2005(2):104-12. doi: 10.1155/JBB.2005.104.

114. Jones GT, Marsman J. DNA methylation profiling identifies a high effect genetic variant for lipoprotein(a) levels. 2020;15(9):949-58. doi: 10.1080/15592294.2020.1739797.

115. Higinbotham KG, Rice JM, Diwan BA, Kasprzak KS, Reed CD, Perantoni AO. GGT to GTT transversions in codon 12 of the K-ras oncogene in rat renal sarcomas induced with nickel subsulfide or nickel subsulfide/iron are consistent with oxidative damage to DNA. Cancer research. 1992;52(17):4747-51.

116. Barciszewska A-M, Giel-Pietraszuk M, Perrigue PM, Naskręt-Barciszewska M. Total DNA Methylation Changes Reflect Random Oxidative DNA Damage in Gliomas. Cells. 2019;8(9):1065. doi: $10.3390 /$ cells8091065.

117. Mund M, Louwen F, Klingelhoefer D, Gerber A. Smoking and pregnancy-a review on the first major environmental risk factor of the unborn. Int J Environ Res Public Health. 2013;10(12):6485-99. doi: 10.3390/ijerph10126485.

\section{Tables}

\section{Table 1}

Clinical features of the women and their offspring 


\begin{tabular}{|c|c|c|c|}
\hline Women & $\begin{array}{l}\text { Non-smokers } \\
(n=188)\end{array}$ & $\begin{array}{l}\text { Smokers } \\
(n=31)\end{array}$ & $p$-value \\
\hline Maternal age (years, mean $\pm S D)^{\&}$ & $23.75 \pm 4.30$ & $22.77 \pm 4.72$ & 0.287 \\
\hline Height $(m, \text { mean } \pm S D)^{\&}$ & $1.57 \pm 0.07$ & $1.59 \pm 0.06$ & 0.068 \\
\hline Pregestational weight $(\mathrm{kg} \text {, mean } \pm \mathrm{SD})^{\text {\& }}$ & $61.89 \pm 10.58$ & $59.67 \pm 13.24$ & 0.365 \\
\hline Pregestational BMI $\left(\mathrm{kg} / \mathrm{m}^{2}\right)^{\&}$ & $25.25 \pm 3.73$ & $23.54 \pm 4.44$ & 0.050 \\
\hline Multi-vitamin intake (\%) $)^{\#}$ & 90.43 & 90.32 & 1 \\
\hline Folic acid supplementation (\%) & 94.68 & 100 & 0.395 \\
\hline Alcohol intake $(\%)^{\#}$ & 3.72 & 19.35 & 0.002 \\
\hline \multicolumn{4}{|l|}{ New-borns } \\
\hline Weight $(g)^{\&}$ & $3158.7 \pm 404.7$ & $3192.6 \pm 379.2$ & 0.650 \\
\hline New-borns' height $(\mathrm{cm})^{\&}$ & $49.31 \pm 1.82$ & $49.18 \pm 2.75$ & 0.803 \\
\hline Birth Delivery $(\%, \mathrm{n}){ }^{\#}$ & $63.30(119)$ & $67.74(21)$ & 0.547 \\
\hline Caesarean $(\%, n)$ & 30.85 (58) & $22.58(7)$ & \\
\hline Unspecified $(\%, n)$ & $5.85(11)$ & $9.68(3)$ & \\
\hline Sex Male $(\%, n)^{\#}$ & $50.0(94)$ & $45.2(14)$ & 0.844 \\
\hline Apgar at 1 minute (median, IQR) ${ }^{\& \&}$ & 8 (8 to 9) & 8 (8 to 9) & 0.881 \\
\hline Apgar at 5 minutes (median, IQR) \&\& & 9 (7 to 9$)$ & 9 (8 to 9$)$ & 0.836 \\
\hline Silverman score (median, IQR) ${ }^{\& \&}$ & 0 (0 to 3$)$ & $0(0$ to 2$)$ & 0.049 \\
\hline Gestational age (weeks, median, IQR) ${ }^{\& \&}$ & 39 (38 to 40$)$ & 39 (38 to 40 ) & 0.583 \\
\hline \multicolumn{4}{|l|}{ \&Student $t$ test. } \\
\hline \multicolumn{4}{|l|}{ \&\&Mann-Whitney Utest. } \\
\hline \multicolumn{4}{|c|}{ \#Pearson chi-square test with Yates' continuity correction. } \\
\hline MI: body mass index; IQR: interquartil & ge. & & \\
\hline
\end{tabular}


Estimated consumptions of energy, macronutrients, and vitamins

\begin{tabular}{|c|c|c|c|}
\hline & $\begin{array}{l}\text { Non-smokers } \\
\text { Median (p25 to p75) } \\
(\mathrm{n}=185)\end{array}$ & $\begin{array}{l}\text { Smokers } \\
\text { Median (p25 to p75) } \\
(n=31)\end{array}$ & $p$-value $e^{\&}$ \\
\hline Energy (kcal/d) & 1881 (1564 to 2503$)$ & 2877 (2016 to 3568 ) & $2.157 e-05$ \\
\hline Carbohydrates (g/d) & 287.0 (244.3 to 381.3$)$ & $410.9(288.8$ to 501.1$)$ & 0.001 \\
\hline Lipids (g/d) & 55.8 (45.1 to 80.6$)$ & 102.1 (69.6 to 112.5$)$ & $8.576 \mathrm{e}-07$ \\
\hline Proteins $(\mathrm{g} / \mathrm{d})$ & 79.5 (61.1 to 114.7$)$ & $138.9(101.0$ to 154.4$)$ & $1.509 \mathrm{e}-06$ \\
\hline Vitamin A (retinol, ER/d) & 619.5 (454.6 to 996.8$)$ & 1030.8 (811.9 to 1282.1$)$ & $2.727 e-05$ \\
\hline Vitamin B12 (cyanocobalamin, $\mu \mathrm{g} / \mathrm{d}$ ) & $3.13(2.3$ to 6.1$)$ & 4.89 (3.47 to 9.2$)$ & 0.001 \\
\hline Vitamin C (ascorbic acid, mg/d) & 161.2 (118.2 to 206.8$)$ & 211.3 (153.2 to 287.2 ) & 0.005 \\
\hline Vitamin E (tocopherols, mg/d) & 4.1 (3.3 to 4.9$)$ & 5.6 (4.4 to 6.8$)$ & $2.443 e-05$ \\
\hline Folic acid (mg/d) & 211.7 (168.6 to 300.5$)$ & 343.0 (240.4 to 486.6$)$ & $1.775 \mathrm{e}-05$ \\
\hline
\end{tabular}

\&Mann-Whitney Utest.

p: percentile. 
Table 3

Association between smoking and oxidant levels

Parameter Model 1, $\beta(95 \% \quad p$

Cl) $p-$
value

Model $2, \beta(95 \% \quad p-$

Cl) value

Model 3, $\beta$

$p-$

$(95 \% \mathrm{Cl})$ value

Mothers' 8-OHdG

$(\mathrm{pg} / \mathrm{mL})$

\begin{tabular}{lllllll} 
Non-smokers & Reference & \multicolumn{2}{c}{ Reference } & \multicolumn{3}{c}{ Reference } \\
Smokers & $-0.84(-1.67$ to & 0.049 & $-1.20(-2.13$ to & 0.012 & $-0.64(-1.54$ to & 0.165 \\
& $-0.01)$ & $-0.27)$ & & $0.27)$
\end{tabular}

\section{New-borns' 8-OHdG} $(\mathrm{pg} / \mathrm{mL})$

\begin{tabular}{|c|c|c|c|c|c|c|}
\hline Non-smokers & Reference & & Reference & & Reference & \\
\hline Smokers & $\begin{array}{l}-0.64(-1.31 \text { to } \\
0.30)\end{array}$ & 0.061 & $\begin{array}{l}-0.96(-1.66 \text { to } \\
-0.26)\end{array}$ & 0.007 & $\begin{array}{l}-0.79(-1.52 \text { to } \\
-0.06)\end{array}$ & 0.033 \\
\hline
\end{tabular}

\section{Methylated DNA (\%)}

\begin{tabular}{lllllll} 
Non-smokers & Reference & \multicolumn{2}{c}{ Reference } & \multicolumn{3}{c}{ Reference } \\
\hline Smokers & $-0.12(-0.21$ to & 0.012 & $\begin{array}{l}-0.12(-0.22 \text { to } \\
-0.02)\end{array}$ & 0.021 & $-0.12(-0.23$ to & 0.029 \\
& $-0.03)$ & & $-0.01)$ & & -0.029
\end{tabular}

Model 1: Robust regression, unadjusted.

Model 2: Robust regression, adjusted for maternal age, alcohol consumption during the first trimester of pregnancy, gestational age (weeks), and body mass index before pregnancy.

Model 3: Robust regression, adjusted for maternal age, alcohol consumption during the first trimester of pregnancy, gestational age (weeks), body mass index before pregnancy, and energy intake (kilocalories).

8-OHdG: 8-hydroxy-2'-deoxy-guanosine; Cl: confidence interval.

\section{Table 4}

Correlations between the mothers' and new-borns' vitamin and 8-OHdG levels 


\section{8-OHdG (pg/mL)}

\begin{tabular}{|c|c|c|}
\hline Mothers ( $n=99$ ) & Rho\& & $p$-value \\
\hline Energy (kcal/d) & -0.460 & $1.57 \mathrm{e}-06$ \\
\hline Carbohydrates (g/d) & -0.407 & $2.89 e-05$ \\
\hline Lipids (g/d) & -0.500 & $1.30 \mathrm{e}-07$ \\
\hline Proteins (g/d) & -0.453 & $2.38 \mathrm{e}-06$ \\
\hline Vitamin A (retinol, ER/d) & -0.417 & $1.67 e-05$ \\
\hline Vitamin B12 (cyanocobalamin, $\mu \mathrm{g} / \mathrm{d}$ ) & -0.363 & 0.0002 \\
\hline Vitamin C (ascorbic acid, mg/d) & -0.141 & 0.161 \\
\hline Vitamin E (tocopherols, mg/d) & -0.292 & 0.003 \\
\hline Folic acid (mg/d) & -0.383 & $8.77 e-05$ \\
\hline New-borns ( $n$ = 182) & Rho & $p$-value \\
\hline Energy (kcal/d) & -0.119 & 0.106 \\
\hline Carbohydrates (g/d) & -0.126 & 0.086 \\
\hline Lipids (g/d) & -0.092 & 0.212 \\
\hline Proteins (g/d) & -0.155 & 0.035 \\
\hline Vitamin A (retinol, ER/d) & -0.204 & 0.005 \\
\hline Vitamin B12 (cyanocobalamin, $\mu \mathrm{g} / \mathrm{d}$ ) & -0.166 & 0.024 \\
\hline Vitamin C (Acid ascorbic, mg/d) & -0.059 & 0.420 \\
\hline Vitamin E (Tocopherols, mg/d) & -0.047 & 0.520 \\
\hline Folic acid (mg/d) & -0.129 & 0.081 \\
\hline
\end{tabular}

\&Spearman rank correlation.

8-OHdG: 8-hydroxy-2'-deoxy-guanosine; p: percentile.

Table 5

Correlations of mothers' and new-born's cigarette consumptions of macronutrients, vitamins, and 8-OHdG levels 


\section{Cigarette consumption}

(Cigarettes per day, $\mathrm{n}=219$ )

\begin{tabular}{lll}
\hline & Rho & $p$-value \\
\hline Mothers' 8-OHdG $(\mathrm{pg} / \mathrm{mL})$ & $-0.247^{\$}$ & 0.012 \\
\hline New-borns' 8-OHdG $(\mathrm{pg} / \mathrm{mL})$ & $-0.029^{\$ \$}$ & 0.694 \\
\hline Alcohol intake & 0.219 & 0.001 \\
\hline Energy (kcal/d) & 0.286 & $1.84 \mathrm{e}-05$ \\
\hline Carbohydrates (g/d) & 0.212 & 0.001 \\
\hline Lipids (g/d) & 0.332 & $5.85 \mathrm{e}-07$ \\
\hline Proteins (g/d) & 0.323 & $1.21 \mathrm{e}-06$ \\
\hline Vitamin A (retinol, ER/d) & 0.287 & $1.72 \mathrm{e}-05$ \\
\hline Vitamin B12 (cyanocobalamin, $\mu \mathrm{gg} / \mathrm{d})$ & 0.217 & 0.001 \\
\hline Vitamin C (ascorbic acid, mg/d) & 0.186 & 0.005 \\
\hline Vitamin E (Tocopherols, mg/d) & 0.283 & $2.35 \mathrm{e}-05$ \\
\hline Folic acid (mg/d) & 0.289 & $1.49 \mathrm{e}-05$ \\
\hline
\end{tabular}

\&Spearman rank correlation, $n=200^{\$}, 213^{\$ \$}$.

8-OHdG: 8-hydroxy-2'-deoxy-guanosine. 


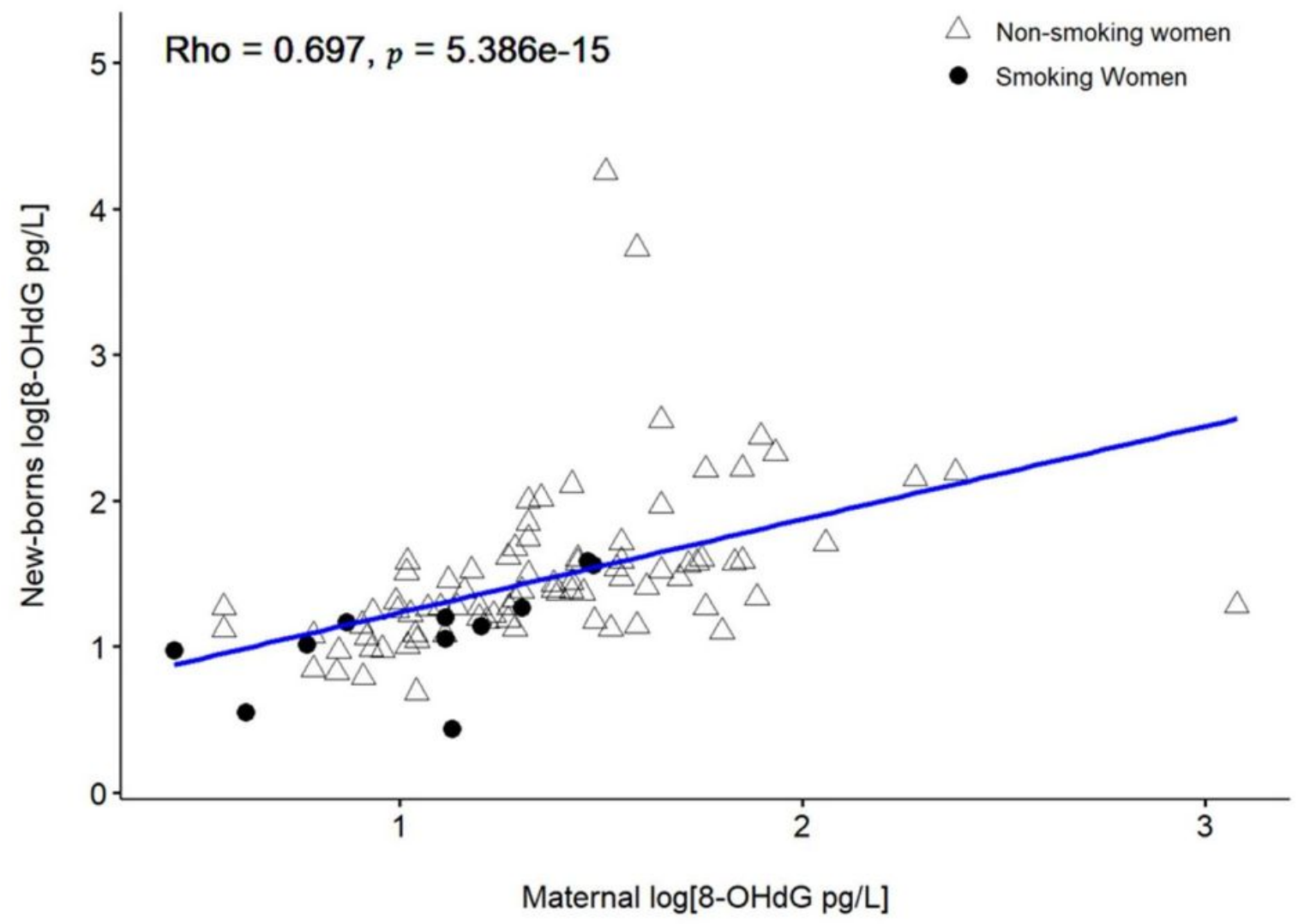

Figure 1

Correlation between the mothers' and new-borns' 8 -OHdG levels. Logarithm transformation was applied to the data. 


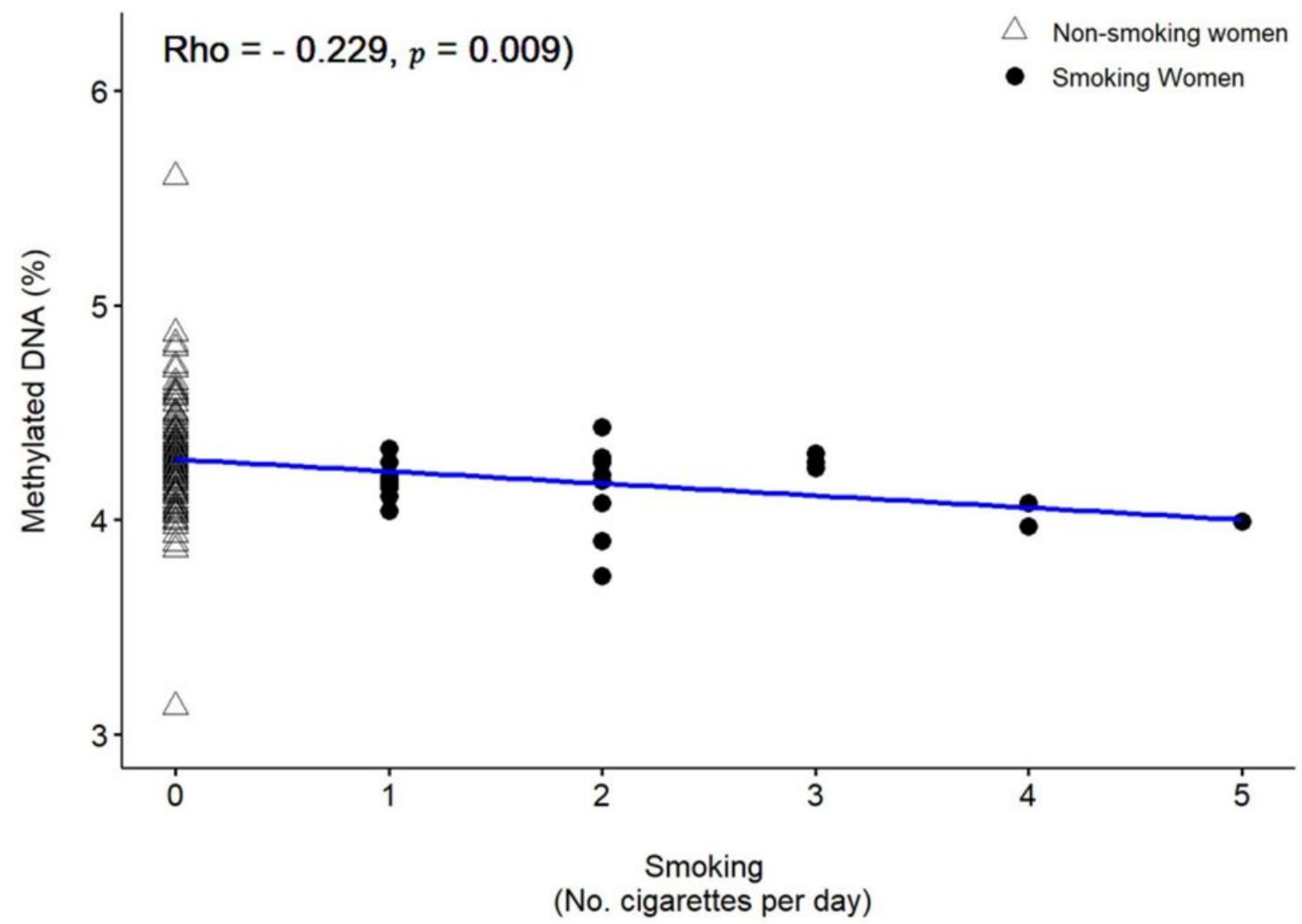

Figure 2

Correlation between placental methylated DNA level and the number of cigarettes consumed per day. 


\section{Smoking}

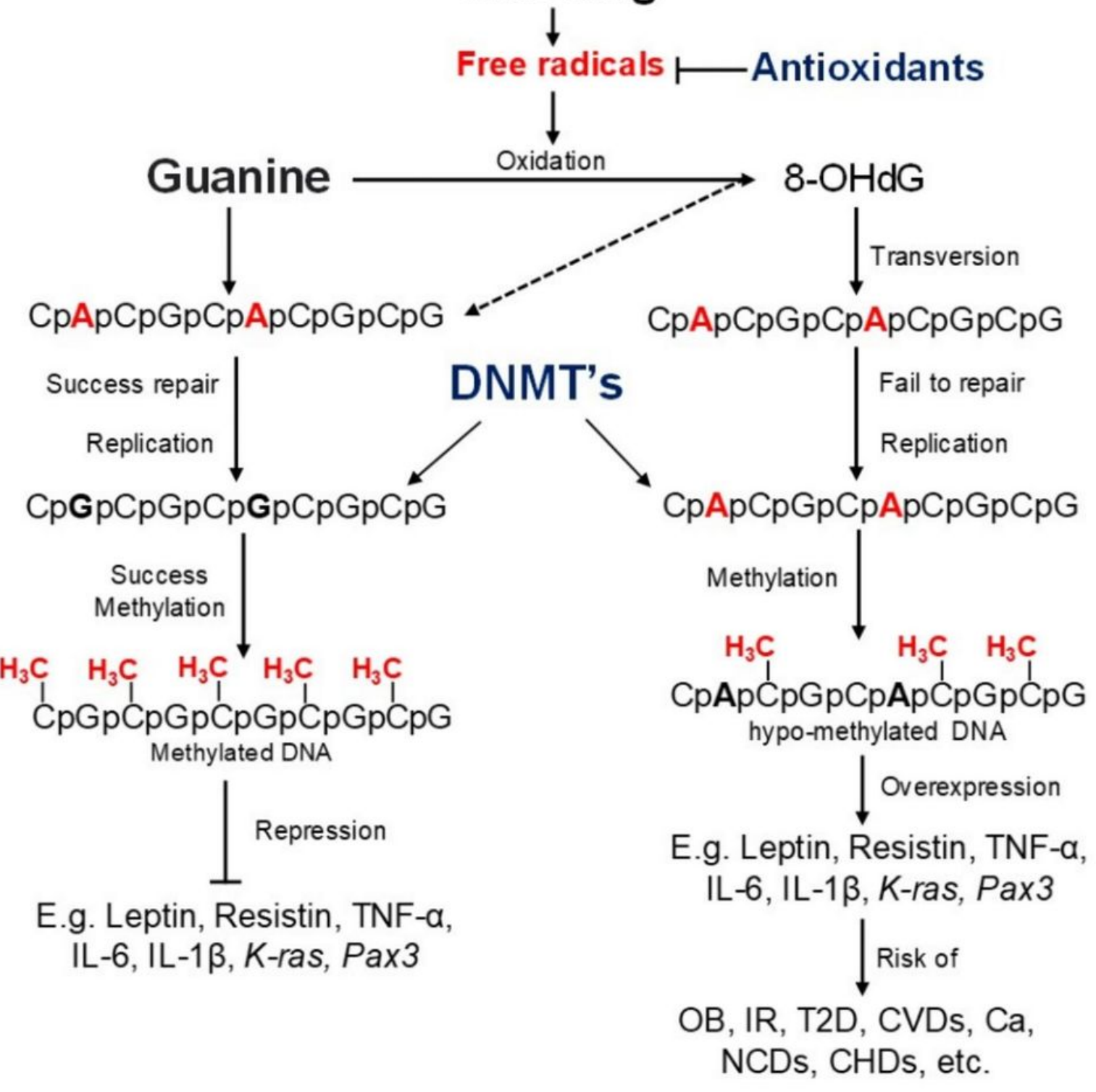

Figure 3

Molecular mechanism by which exposure to cigarette smoke could cause DNA hypomethylation. Under normal conditions, DNA replication gives rise to two strands with an identical nucleotide number and sequence, preserving the genetic identity throughout cell generations [102]. Amongst the nucleotides, guanines have lower reduction potentials, making them the main abductors for FRs; thus, throughout several chemical changes, the guanine-to-FR interaction give rise to 8-hydroxy-2'-deoxy-guanines (8-OHdG) [36, 103]. Cigarette smoke produces huge quantities of FR $[35,48]$, which could increase the rate of 8-OHdG synthesis in smokers. Owing to its structure, 8-OHdG pairs easily with thymine instead of cytosine, stimulating transversions $(\mathrm{G} \rightarrow \mathrm{T})$ during DNA replication [79]. Regardless of whether DNA repair mechanisms revert the change (T to G)[104], 
thymine is preserved instead of guanine in the next cell generations. Cytosine-guanine islands (CpGls) are widespread in the human genome and found in an estimated $80 \%$ of human gene promoters [83-85]. CpGls regulate gene expression by cytosine methylation via DNA methyl transferases (DNMTs), which use the methyl group $\left(-\mathrm{CH}_{3}\right)$ to transfer from S-adenosylmethionine (SAM) to cytosine, producing 5-methycitocines (5mCs) [105]. Once $5 \mathrm{mCs}$ are established, transcription factors can no longer bind the gene promoters, causing gene repression or suppression [80-82]. 8-OHdG itself can avoid the recognition and binding of DNMTs to CpGls [80]. Induced by SC, both mechanisms could cause DNA hypomethylation. Aberrant changes in the methylated DNA patterns, specifically hypomethylation, have been associated with the risk of developing pathologies such as obesity (OB) [106], insulin resistance (IR) [107-112], type 2 diabetes (T2D) [113], cardiovascular diseases (CVDs) [112, 114], different types of cancer (Ca) $[115,116]$, congenital neuronal defects (NCDs), and congenital heart defects (CHDs) [16, 82], amongst other complications [117].

\section{Supplementary Files}

This is a list of supplementary files associated with this preprint. Click to download.

- supplementaryfile1.csv 